\title{
PUCCOONS IN SASKATCHEWAN
}

\section{VERNON L. HARMS, \#212-115 Keevil Crescent, Saskatoon, SK S7N 4P2}

Among the wild flowers brightening our native prairies in late spring and early summer are the yellow- or orange-flowered puccoons. Also known as gromwells, or sometimes as stoneseeds, the puccoons are classified in the genus Lithospermum belonging to the Borage Family (Boraginaceae). Saskatchewan has three native species, two of which are common prairie or open parkland plants in the southern third of the province, and the third, a rarity found only in the West Block of the Cypress Hills (see Maps 1-3).
Our three puccoons are perennial herbs with thick, woody, purplish-brown taproots, giving rise to tufts of hairy stems, 2-5 dm high, that bear numerous, alternate, unstalked, hairy leaves (Fig 1). The pleasantly fragrant flowers are radially symmetrical, with a calyx of five nearly separate sepals, a corolla of five yellow petals fused to form a tube flaring out above into a 5-lobed limb. Five prominent folds or appendages (collectively called a crest or fornice) are often present at the corollathroat, between the tube and limb (see

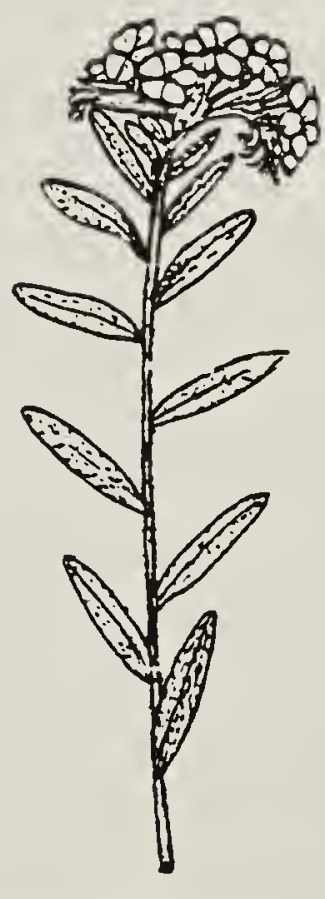

Hoary Puccoon

(L. canescens)

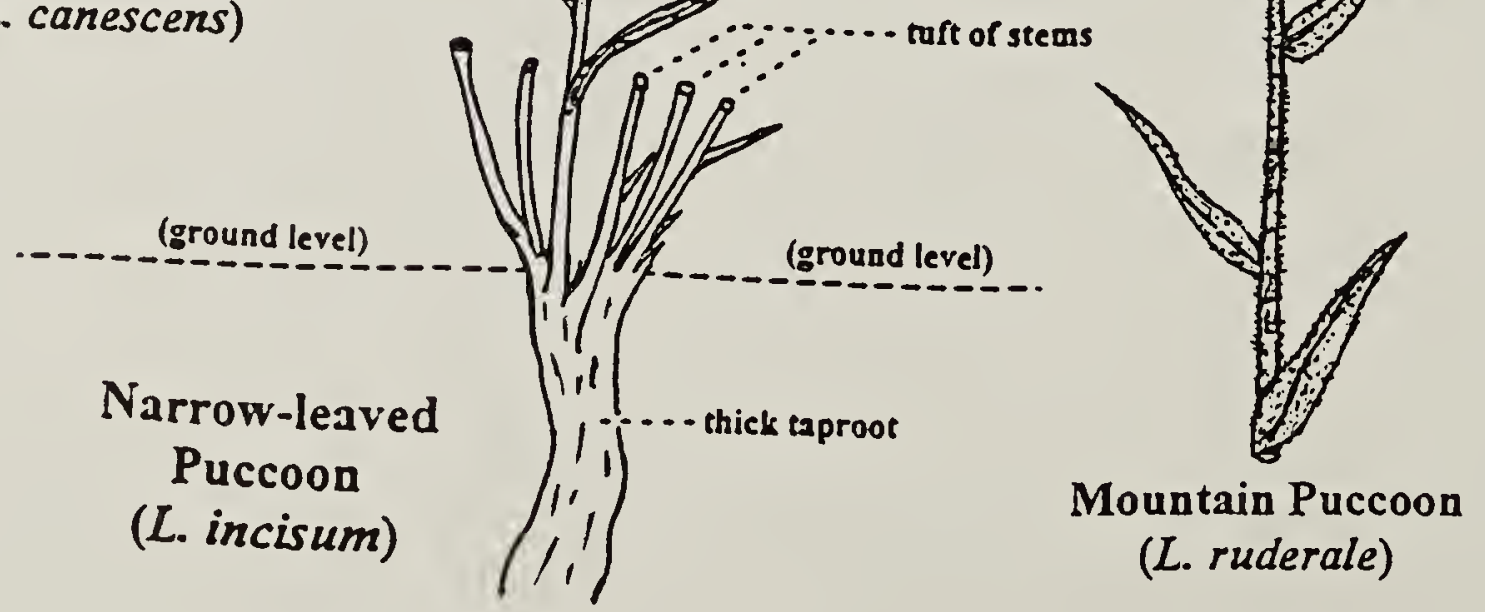

Figure 1. The native puccoon (Lithospermum) species in Saskatchewan 

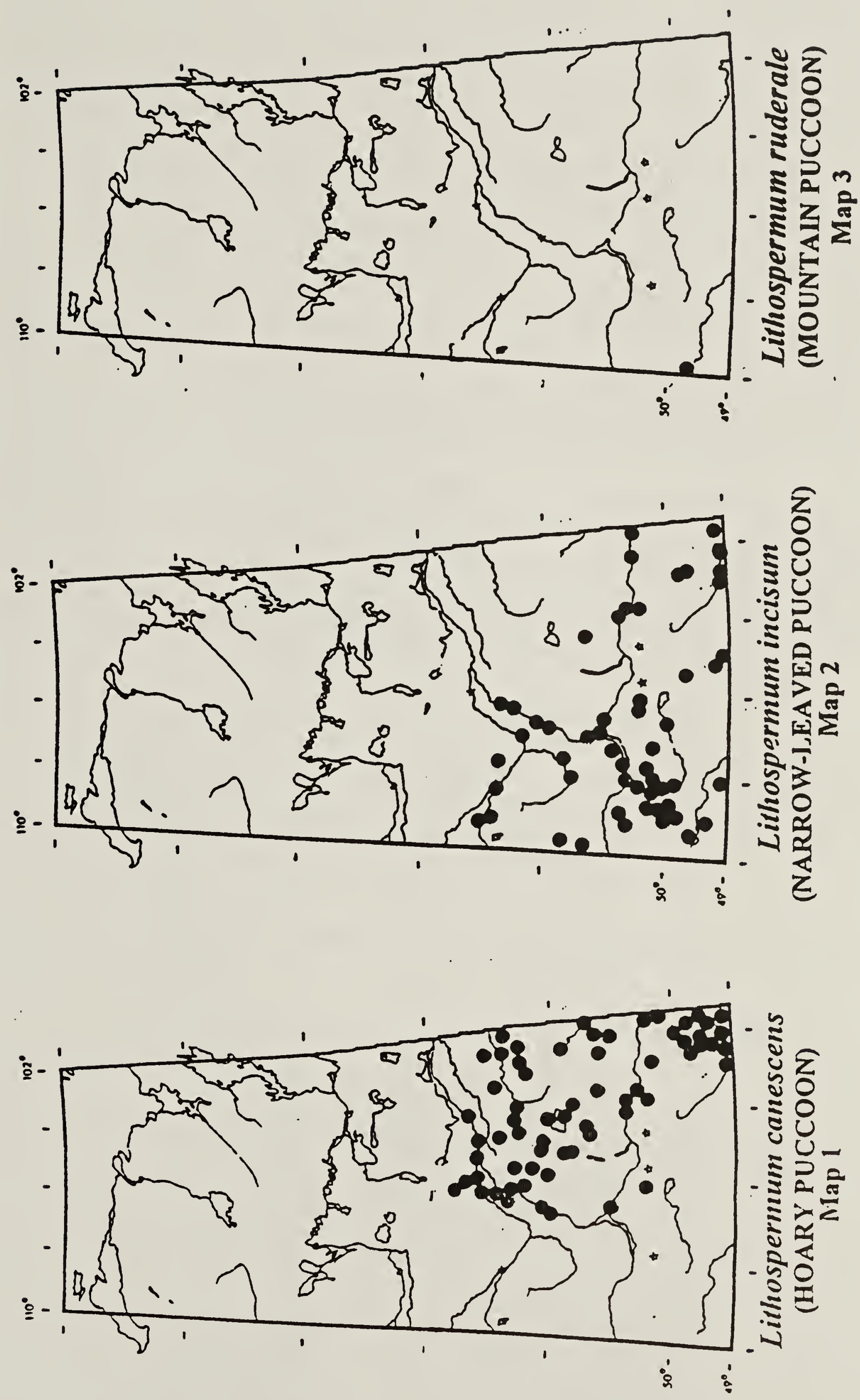

Maps 1-3. Distributional Records of Puccoon (Lithospermum) species in Saskatchewan 
diagrams in Fig. 2). The five stamens are inserted within the corolla-tube above the middle. The pistil consists of a single style bearing a 2-lobed stigma arising from a deeply 4-lobed superior ovary that at fruitmaturity splits into four separate nutlets, each containing a single seed. These nutletfruits are notably hard, shiny, ivory-white and porcelain-like. In the Narrow-leaved Puccoon, two types of flowers are present. The earliest flowers are open and large (chasmogamous), while the later season flowers are much smaller and remain closed (cleistogamous), but selffertilization occurs in the latter and they actually produce most of the fertile nutlets.

The genus name, Lithospermum, is a combination of the Greek word lithos (meaning "stone") and sperma (meaning "seed"), and can be literally translated as a "stony seed", referring to the distinctive, hard, shiny white nutlets. The common name "puccoon" is derived from the American Indian word pokan, a term applied to various plants producing red or yellow pigments usable for dyes. Even today, the common name "puccoon" is sometimes applied to other dye-producing plants in North America besides Lithospermum species, such as to Bloodroot (Sanguinaria canadensis of the poppy family) and Goldenseal (Hydrastis canadensis of the buttercup family). The meaning of the alternative common name "gromwell" appears less clear. From Middle English and probably of Old French origin, it was long applied to the European species, Lithospermum officinale, and represents the Old World name carried over to other species of the genus.

The taxonomic key on the following page may be used to identify our Saskatchewan puccoon species.

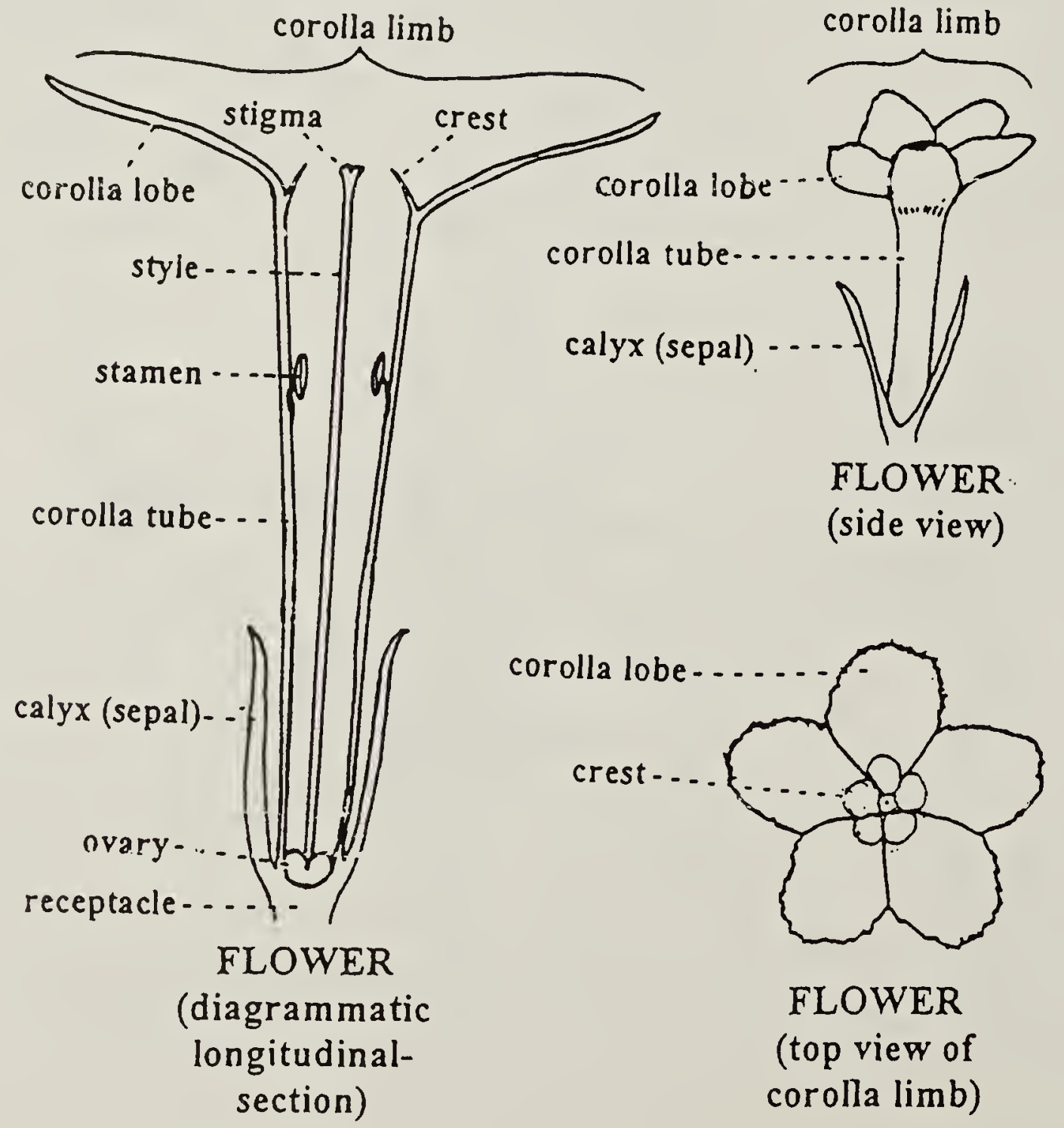

Figure 2. Puccoon (Lithospermum) flowers (diagrammatic) 
1a. Leaves narrowly linear, over 8 times longer than wide, mostly less than $5 \mathrm{~mm}$ broad, sharp-tipped; both leaves and stems with short, stiff, appressed hairs; two types of flowers present, the earliest open and large, but those of later season remaining closed and small; corollas an intense light lemon-yellow, those of the opened (large) flowers with tubes 1-2 cm long and limbs 1-2 cm broad, the lobe-tips with small jagged as well as rounded teeth; corollas of the later closed flowers only 2-6 mm long; nutlets 3-4 mm long, with pitted surfaces, and a distinct collar-like flange below a basal constriction; stems to $4(-5)$ dm tall; fruiting stalks mostly arching.

\section{L. incisum.}

1b. Leaves broader, narrowly to broadly lance-shaped or elliptic; only one type of flower present, lacking permanently closed reduced flowers; corolla lobe-tips entire or very nearly so; flower clusters (cymes) appearing larger because all, not just the first few, flowers are open and sizeable; nutlets smooth, lacking pits or a basal collar; leaves and stems with at least some spreading hairs; fruiting stalks mostly erect.

$$
\text { (to } 2 \text { ). }
$$

2a. Primary leaves mostly oblong to broadly lance-shaped, blunt-tipped, over $4 \mathrm{~mm}$ broad, mostly less than $5 \mathrm{~cm}$ long, less than eight times longer than wide; hairs on leaves and stems finer and softer; upper leaves not crowded or obscuring flowers; corollas a vivid orange or yellow-orange to deep yellow, with prominent throatfolds (crest), the tubes $8-18 \mathrm{~mm}$ long, and the limbs mostly $1.0-1.5 \mathrm{~cm}$ broad; calyx 5 to17 mm long; nutlets only 2-3 mm long; stems 1-3 dm tall, with only spreading

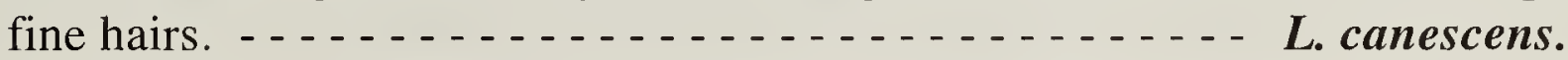

2b. Primary leaves narrowly lance-shaped, mostly sharp-tipped, to $8 \mathrm{~cm}$ long, the upper leaves crowded and obscuring flowers; stems and leaves more coarsely and harshly hairy; corollas dull greenish-yellow to pale yellow, smaller, with tubes only 5-8 $\mathrm{mm}$ long and limbs less than $1 \mathrm{~cm}$ broad, lacking throat-folds (crest); calyx about $5 \mathrm{~mm}$ long, much shorter than corolla-tube; nutlets mostly 4 to $6 \mathrm{~mm}$ long; stems $2-$ $5 \mathrm{dm}$ high, with both appressed and spreading coarse hairs.

L. ruderale.

Figure 3. Typical leaf shapes of puccoon (Lithospermum) species in Saskatchewan

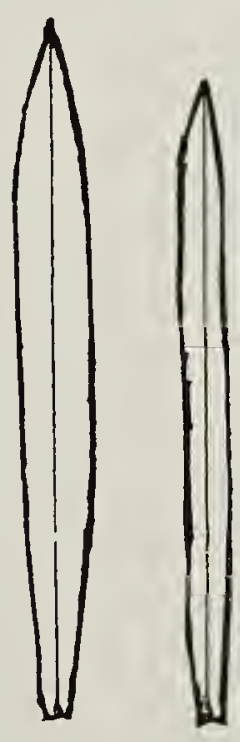

Narrow-leaved

Puccoon

(L. incisum)
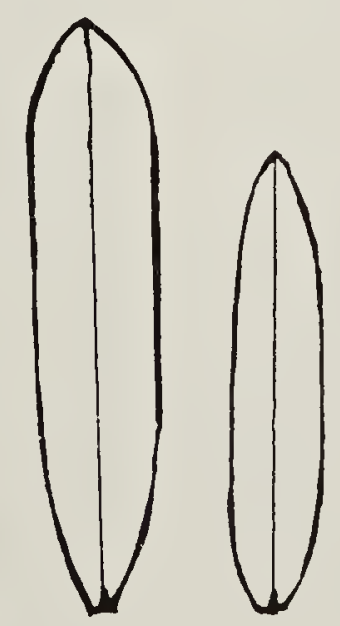

Hoary Púćcoon (L. canescens)

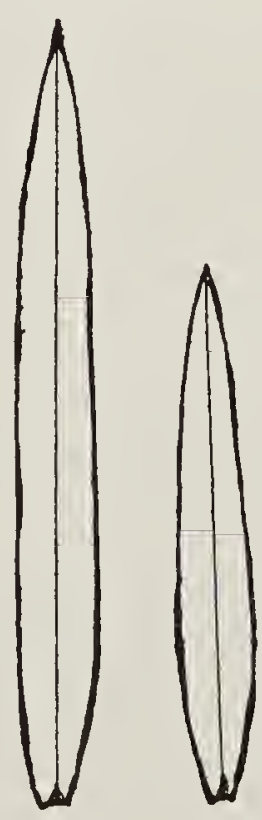

Mountain

Puccoon

(L. ruderale) 
Lithospermum canescens (Michx.) Lehm. - HOARY PUCCOON / GROMWELL.

This is an eastern species in North American, ranging from Ontario west to southern Saskatchewan, and south to Georgia, Mississippi and Texas. In Saskatchewan, it ranges westward only to about the $107^{\circ}$ meridian, not much west of Saskatoon. In this province, it is most numerous on open grassy sites in the parkland region, but is also found somewhat south of the parkland in the northern mixedgrassland region (see Map 1). It may be distinguished from the also common Narrow-leaved Puccoon by the characters given in the above key, especially by (1) the leaves being broader, blunt-tipped and mostly oblong (see Fig. 3), (2) both stems and leaves with finer and more spreading hairs, (3) the corollas deeper yellow to usually yellow-orange or bright orange, with lobes scarcely toothed, if at all, (4) no permanently closed and reduced flowers present, (5) flower clusters more conspicuous, (6) nutlets somewhat smaller with smooth unpitted surfaces, and (7) fruiting stalks mostly erect rather than arching. (See Fig. 1 for its generalized plant habit). The specific epithet is derived from the Latin word canus meaning "grayish white" or "hoary", referring to its grayish aspect due to the hairs overlying the plant surfaces. This likewise explains its common name.

\section{Lithospermum incisum Lehm. -} NARROW-LEAVED or FRINGED PUCCOON I GROMWELL I STONESEED. [Synonyms: L. angustifolium Michx.; L. linearifolium Goldie]. This is a widespread grassland species occurring across the Canadian Prairie Provinces, ranging overall from British Columbia to Ontario, and somewhat discontinuously south to California, Northern Mexico, Texas, Tennessee and Florida. In Saskatchewan, the Narrow-leaved Puccoon is most common in open prairie habitats across the grassland region of the province, extending only into the southernmost fringe of the parkland region where it is much less frequent than the Hoary Puccoon (see Map 2). It may be distinguished by the characters given in the above key, notably by (1) its leaves being more narrowly linear (see Fig. 3) with all hairs appressed, stiff and short, (2) its corolla a lighter lemon-yellow, with toothed lobes, (3) the presence of two types of flowers with only the first few open and large and the later ones reduced and remaining closed, (4) its pitted nutlets, and (5) mostly arching fruiting stalks. (See Fig. 1 for its generalized plant habit). The specific epithet is from the Latin word incisus meaning "cut deeply and sharply", referring to the often jagged although actually rather minutely toothed corolla-lobes. Its common names refer respectively to its narrow leaves and fringed corolla lobes (Fig. 4).

Lithospermum ruderale Dougl. ex Lehm. -MOUNTAIN, COLUMBIAN or WOOLLY PUCCOON / GROMWELL. This is a more western species in North America, ranging from British Columbia east to southwestern Saskatchewan, and south to California and Colorado. Although quite common farther west, especially in grasslands of the Alberta foothills, it is rare in Saskatchewan where it is recorded from open grassy habitats only along Battle Creek in the West Block of the Cypress Hills near the Alberta border (see Map 3). This species may be distinguished by the characters given in the above key, notably by (1) plants mostly taller, coarser, and more leafy, (2) stems thicker and more numerous in tufts, (3) hairs of stems and leaves coarser, (4) primary leaves mostly oblong (see Fig. 3), (5) nutlets larger, (6) corollas smaller, dull pale yellow to greenish-yellow, and lacking a throat-crest, and (7) calyx always short. (See Fig. 1 for its generalized plant habit). The specific epithet is derived from the Latin word ruderalis, literally meaning "growing among rubbish", i.e. in disturbed places or waste ground. The common names "Mountain" and "Columbian Puccoon" are geographical depictions, while "Woolly Puccoon" describes the coarse hairiness of the plants. 


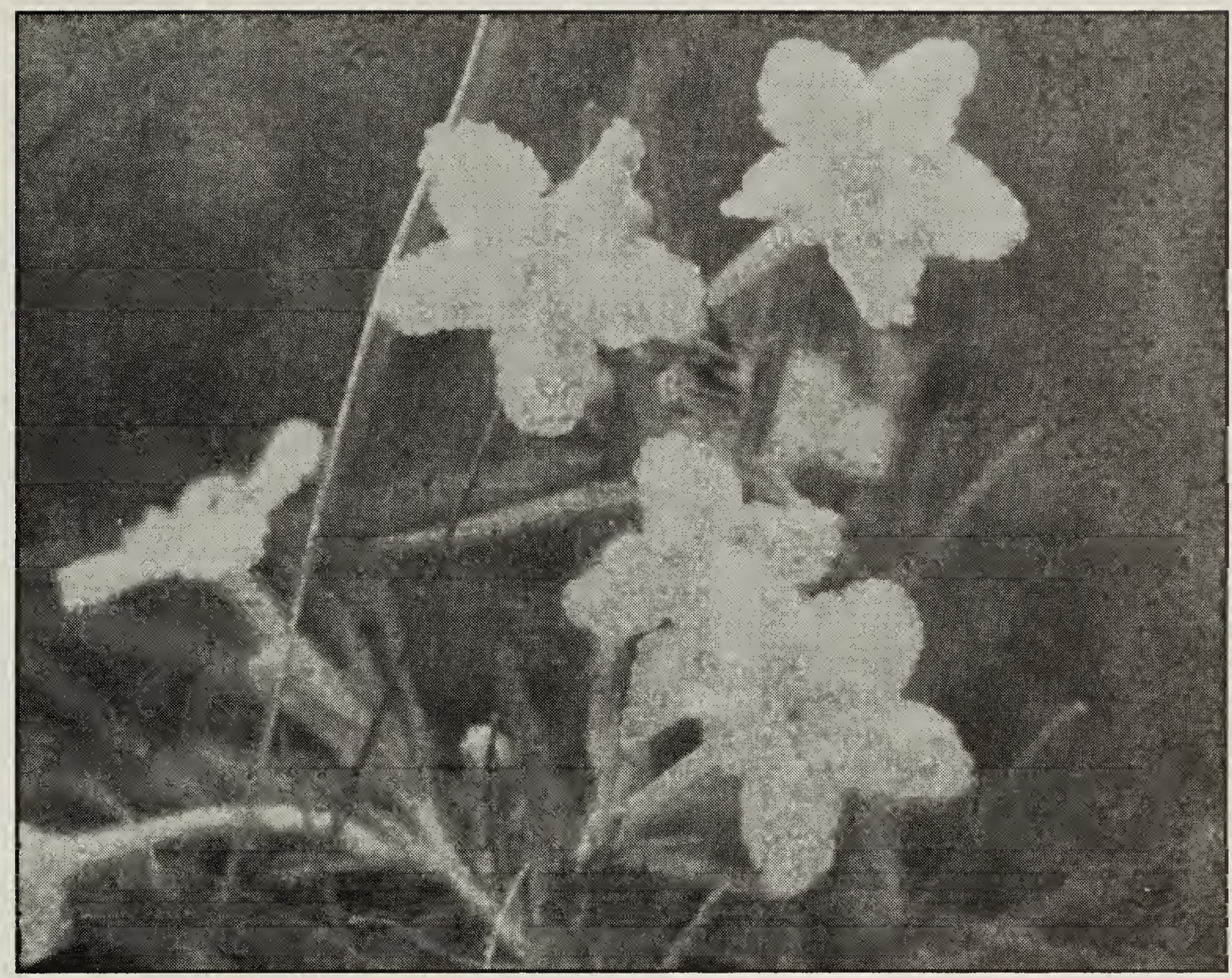

Figure 4. Narrow-leaved Puccoon

Anna Leighton

Puccoon plants have had numerous uses, especially historically by various North American aboriginal tribes. After being pulverized and dried, the large taproots were the source of a brilliant red dye used for various purposes. ${ }^{1,2}$ An infusion of the powdered roots was applied externally for its calming effects and to reduce swellings ${ }^{2}$, and, mixed with grease and ashes, spread as a salve, to conserve body heat, and to even repel insects.' The powdered roots were used for chest wounds and lung hemorrhages. ${ }^{2}$ A cold water tea made from the roots of Narrow-leaved Puccoon was reportedly used by Navaho women as a contraceptive, its effectiveness apparently due to the presence of a natural estrogen that suppresses the pituitary's secretion of gonadotropins. The dried tops and sometimes roots were burned as an incense at ceremonials, producing a pleasant and alluring aroma. ${ }^{1,2}$ Sacred beads were sometimes made by stringing the hard, shiny, white nutlets. ${ }^{2}$ The thick taproots were reportedly used as food by some aboriginal people, apparently after pounding the woody roots into a sort of flour that was then boiled in fat-broth. ${ }^{1}$

Puccoons are certainly attractive and interesting wild flowers. When again roaming Saskatchewan's native prairies and parklands in early summer, take note of these bluish-green plants with their small, yet strikingly vivid yellow or orange blossoms.

1. KEANE, K. 2002. Puccoons have many uses. Herbal Hints. The Saskatoon Sun, May 12, 2002

2. MOERMAN, D. E. 1998. Native American Ethnobotany Database: Foods, Drugs, Dyes, and Fibers of Native North American Peoples. Timber Press, Portland, OR. 927 pp. [http:/ /www.umd.umich.edu/cgi-bin/herb/]. 


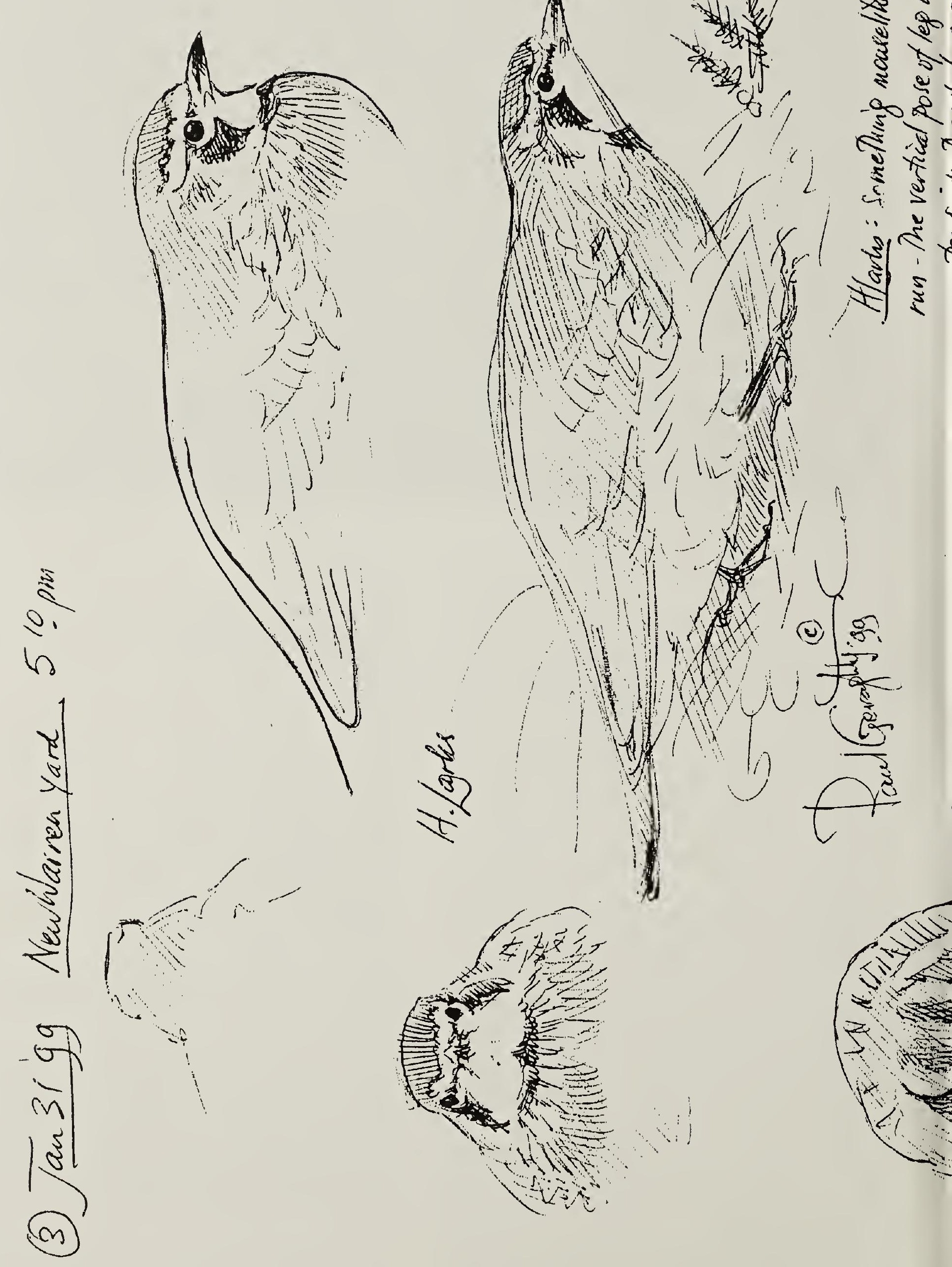




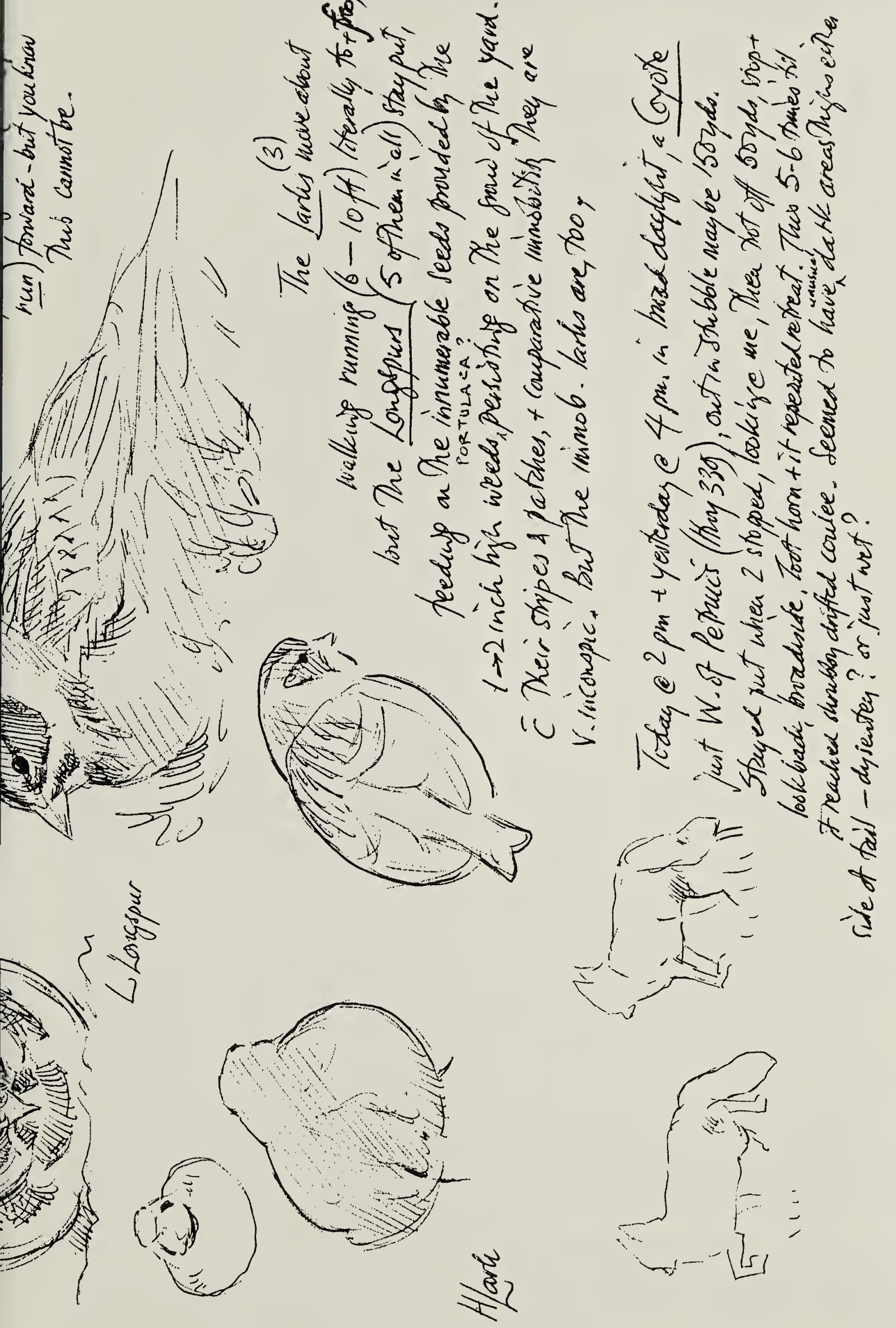

